ARTIKEL PENELITIAN

\title{
Hubungan kadar imunoglobulin a sekretori air susu ibu dengan berat badan bayi yang mendapat air susu ibu eksklusif
}

\author{
Malinda Meinapuri, Biomechy Oktomalio Putri \\ Bagian Histologi FK Unand
}

Korespondensi: Malinda Meinapuri,email: malindameinapuri23@gmail.com

\begin{abstract}
Abstrak
Menyusui adalah cara terbaik dalam memberikan nutrisi ideal untuk pertumbuhan dan perkembangan bayi. Air Susu Ibu (ASI) mengandung protein dengan fungsi imunologis yaitu Immunoglobulin A (IgA) sekretori, laktoferin, dan lisozym. IgA sekretori dalam ASI berfungsi melindungi bayi dari infeksi bakteri, virus, maupun parasit. Tujuan: Untuk mengetahui hubungan kadar imunoglobulin A sekretori dalam ASI dengan berat badan bayi yang mendapat ASI eksklusif. Metode: Penelitian ini menggunakan desain potong lintang yang diselenggarakan di RSUP M Djamil, beberapa puskesmas, dan Laboratorium Biomedik Fakultas Kedokteran Universitas Andalas. Subjek penelitian adalah ibu dan bayi yang melaksanakan ASI eksklusif, berumur 4-6 bulan, dan bersedia ikut penelitian. Jumlah sampel minimal 59 subjek dan diambil secara consecutive sampling. Analisis statistik dengan Analisis Bivariat Korelasi Pearson. Didapatkan 60 subjek ikut serta dalam penelitian. Hasil: Jenis kelamin terbanyak perempuan yaitu $51,67 \%$ dengan usia bayi rata-rata 4,5 bulan. Berat badan rata-rata $6,75 \mathrm{~kg} \mathrm{SD}+0,95$. Kadar IgA sekretori rata-rata $17,3 \mathrm{ng} / \mathrm{ml}, \mathrm{SD}+3,14$. Didapatkan nilai p hubungan kadar IgA sekretori dalam ASI dan berat badan 0,908. Kesimpulan: Kadar imunoglobulin A sekretori dalam ASI tidak berhubungan dengan berat badan pada bayi yang mendapat ASI eksklusif. Kata kunci: IgA sekretori; ASI eksklusif; berat badan bayi
\end{abstract}

\section{Abstract}

Breastfeeding is the best way to provide the ideal nutrition for baby growth and development. Breast milk contains proteins with immunological function of Immunoglobulin A (IgA) secretory, lactoferrin, and lysozyme. Secretory IgA in breast milk protects infants against bacterial, viral, and parasitic infections. Objective: To determine the relationship of secretory immunoglobulin A levels in breast milk with infant weight exclusively breastfed. Method: This study used cross sectional design that was held in RSUP M. Djamil, some Public health Centre, and Biomedical Laboratory of Medical Faculty Universitas Andalas. Subjects were mothers and infants who carried out exclusive breastfeeding, aged 4-6 months, and were willing to take part in the study. The sample size was at least 59 subjects and taken by consecutive sampling. Statistical analysis with parson correlation bivariate analysis. Obtained 60 subjects participated. Result: The most female sex $51.67 \%$ with baby age average 4.5 month. Weight average $6.75 \mathrm{~kg} S D \pm 0.95$. Secretary $\mathrm{IgA}$ concentration averaged $17.3 \mathrm{ng} / \mathrm{ml}, S D \pm 3.14$. Obtained $p$ value relation of secretory IgA level in breast milk and body weight 0.908 . Conclusion: Immunoglobulin A secretory level in breast milk was not associated with weight gain in exclusively breast-fed infants.

Keywords: secretory IgA; exclusive breastfeeding; infant weight 


\section{PENDAHULUAN}

Menyusui memberikan berbagai manfaat bagi bayi, ibu, keluarga, dan masyarakat, dan merupakan cara alami untuk mendapatkan nutrisi yang baik, meningkatkan daya tahan tubuh serta memelihara emosi selama masa pertumbuhan dan perkembangan bayi. ${ }^{1,2}$ Air susu ibu (ASI) mengandung zat nutrisi yang dibutuhkan serta faktor antibakteri dan antivirus yang melindungi bayi terhadap infeksi. Air Susu lbu dapat mengurangi kejadian berbagai infeksi selama masa bayi dan balita terhadap gastroenteritis, infeksi saluran pernapasan, otitis media, sepsis neonatorum, dan infeksi saluran kemih. Hampir $90 \%$ kematian balita terjadi di negara berkembang dan lebih dari $40 \%$ kematian disebabkan diare dan infeksi saluran pernapasan akut. Penyakit saluran cerna dan saluran nafas dapat dicegah dengan pemberian ASI eksklusif. ${ }^{2}$

Menyusui secara eksklusif akan menjamin terpenuhinya nutrisi dan berbagai manfaat dari ASI, seperti perkembangan dan perlindungan terhadap infeksi dan beberapa penyakit kronik lainnya. ${ }^{1}$ Pemberian ASI secara eksklusif direkomendasikan sampai bayi berusia 6 bulan ketika makanan yang padat mulai diperkenalkan, dan dilanjutkan sampai usia 12 bulan atau lebih, selama yang diinginkan oleh ibu dan anak. ${ }^{1,3}$

Angka dimulainya pemberian ASI sejak dini cukup tinggi di Australia, yaitu 96\%, namun hanya $15 \%$ bayi yang pada akhirnya mendapat ASI eksklusif sampai usia 6 bulan. ${ }^{1}$ Data dari National Immunization Survey di Amerika pada tahun 2004, angka menyusui adalah 70,3 \% untuk pernah menyusui, 36,2\% untuk menyusui yang dilanjutkan pada bulan ke-6, 38,5\% untuk ASI eksklusif pada bulan ke-3, dan 14,1\% untuk ASI eksklusif pada bulan ke-6. Sementara menurut survei pada Ibu oleh Divisi Produk Ross Abbott pada 2004, $64,7 \%$ ibu menyusui di rumah sakit, $31,9 \%$ menyusui pada bulan ke-6, dengan $41,7 \%$ ibu memberikan ASI eksklusif di rumah sakit dan 17,4\% yang memberikan ASI eksklusif pada bulan ke-6. Peningkatan tren ini cukup baik, namun masih di bawah target Healthy People 2010, yaitu sejumlah $75 \%$ ibu menyusui segera setelah melahirkan, 50\% pada bulan ke-6, dan 25\% pada bulan ke-12. ${ }^{4}$ Penggunaan ASI di Indonesia masih sangat kurang. Berdasarkan Survei Demografi Kesehatan Indonesia (SKDI) 2002, hanya 3,7\% bayi yang memperoleh ASI pada hari pertama. Pemberian ASI pada bayi usia <2 bulan sebesar $64 \%$, 2-3 bulan sebesar $45,5 \%$, 4-5 bulan sebesar 13,9\%, dan 6-7 bulan sebesar $7,8 \%$. Sementara itu, cakupan pemberian susu formula meningkat 3 kali lipat dari tahun 1997 ke $2002 \quad(10,8 \%$ menjadi $32,4 \%) .^{5}$

Menyusui mempertahankan proteksi ibubayi setelah kelahiran dengan membantu transfer faktor maternal yang memodulasi sistem imun pada periode yang krusial di saat bayi sedang mengembangkan imunitasnya sendiri. Perlindungan ini diperoleh dari adanya berbagai protein fungsional, seperti imunoglobulin $A$, laktoferin, faktor pertumbuhan, dan sitokin. Di antara berbagai komponen susu, laktoferin berperan penting dalam pertahanan terhadap penyakit, terutama di saluran cerna. ${ }^{6}$ 
Air Susu Ibu merupakan produk oleh kelenjar mamae yang terdapat pada payudara. ${ }^{4}$ Air Susu Ibu merupakan nutrisi ideal untuk menunjang kesehatan, pertumbuhan, dan perkembangan bayi secara optimal. ASI mengandung lemak, karbohidrat, protein, nutrien mikro, dan antibodi dalam jumlah yang tepat untuk pencernaan, perkembangan otak, dan pertumbuhan bayi. Kandungan zat aktif lain dalam ASI yang terutama bekerja untuk fungsi kekebalan tubuh adalah komponen protein ( $\alpha$-laktabumin, $\beta$-laktaglobulin, kasein, enzim, faktor pertumbuhan, hormon, laktoferin, lisozim, slgA, dan imunoglobulin lain), nitrogen nonprotein lain ( $\alpha$-amino nitrogen, keratin, kreatinin, glukosamin, asam nukleat, nukleotida, poliamin, urea, asam urat), karbohidrat (laktosa, oligosakarida, glikopeptida, faktor bifidus), lemak (vitamin larut dalam lemak: A, D, E, K, karotenoid, asam lemak, fosfolipid, sterol dan hidrokarbon, trigliserida), vitamin yang larut dalam air (biotin, kolin, folat, inositol, niasin, asam pantetonat, riboflavin, thiamin, vitamin B12, vitamin B6, vitamin C, mineral, dan ion (kromium, kobalt, copper, fluorid, iodin, mangan, molibdenum, nikel, selenium, dan seng), serta sel (epitel, leukosit, limfosit, makrofag, dan neutrofil). Sehingga dapat dimengerti dengan mendapatkan ASI, bayi mendapatkan kekebalan terhadap berbagai penyakit, seperti radang paruparu, radang telinga, diare, dan juga mengurangi risiko alergi. ${ }^{4,7}$

Beberapa studi mengemukakan efek proteksi dari ASI. Di negara berkembang, insiden gastroenteritis, penyakit pernafasan, morbiditas dan mortalitas lebih rendah pada bayi yang mendapat ASI daripada bayi yang mendapat susu pengganti. Di negara maju seperti $A S$, bayi yang mendapat ASI lebih jarang menderita diare, penyakit saluran nafas bagian bawah, otitis media akut dan rekuren, serta infeksi saluran kencing. Willer dan rekan mengemukakan bahwa ASI bisa menghambat adhesi dan invasi Shigella, sehingga mencegah shigellosis pada bayi. ${ }^{8}$

Komposisi ASI yang diproduksi oleh ibu yang melahirkan bayi kurang bulan (ASI prematur) berbeda dengan komposisi ASI yang diproduksi oleh ibu yang melahirkan bayi cukup bulan (ASI matur). Komposisi ASI yang keluar pada hari-hari pertama sampai hari ke-5 (kolostrum) berbeda dengan ASI yang diproduksi pada hari ke-8 sampai ke-11 (ASI transisi), dan selanjutnya (ASI matur). Komposisi tersebut sesuai dengan kebutuhan bayi pada keadaan masing-masing. ASI dari ibu yang melahirkan bayi prematur sesuai dengan kebutuhan bayi prematur dan juga sebaliknya ASI dari ibu yang melahirkan bayi cukup bulan sesuai dengan kebutuhan bayi cukup bulan tersebut. ${ }^{9}$

Imunoglobulin adalah suatu glikoprotein yang berespons terhadap masuknya protein asing yang disebut antigen. Imunoglobulin terdiri dari beberapa jenis yang disebut isotipe, yaitu imunoglobulin $A$ $(\lg A)$, imunoglobulin $D(\lg D)$, imunoglobulin E (IgE), imunoglobulin G (IgG), dan imunoglobulin $\mathrm{M}(\operatorname{IgM}) \cdot{ }^{10-12}$

IgA merupakan imunoglobulin yang mempunyai 2 bentuk, yaitu bentuk monomer yang umumnya berada dalam sirkulasi dan bentuk polimer yang dikenal dengan IgA sekretori. IgA sekretori adalah imunoglobulin yang dibentuk oleh epitel 
mukosa dan dapat ditemukan dalam berbagai sekret tubuh seperti saliva, air susu, cairan bronkial, cairan pleura, cairan saluran cerna, dan sekret vagina. Satu molekul IgA sekretori dibentuk oleh rantai ringan, rantai berat, komplemen sekretori, dan rantai penyambung J. IgA sekretori adalah komponen utama pertahanan mukosa. ${ }^{10-12}$

Peranan IgA sekretori dalam ASI telah disebutkan pada berbagai kepustakaan untuk melindungi bayi dari berbagai infeksi bakteri, virus, maupun parasit. ${ }^{13,14}$ IgA sekretori berperan terhadap infeksi bakteri seperti, Eschericia coli, Helicobacter pylori, Salmonella, Shigella sp, Clostridium tetani, Corynebacterium diphteriae, Klebsiela pneumoniae, Haemophilus influenzae, Streptococcus pneumonia. ${ }^{13}$ IgA sekretori juga berperan terhadap infeksi virus seperti Rotavirus, Polio, Rubella, CMV, Influenza, dan Respiratory Synctitial Virus (HSV). ${ }^{13}$ IgA sekretori juga berperan terhadap infeksi parasit seperti Giardia lambdia, dan Entamoeba histolitika. ${ }^{13}$

Masa tumbuh kembang bayi 0-6 bulan membutuhkan asupan gizi yang diperoleh melalui pemberian ASI eksklusif. Gangguan tumbuh kembang pada 18 awal kehidupan bayi dapat disebabkan karena kekurangan gizi sejak bayi, pemberian makanan pendamping ASI yang terlalu dini atau terlalu lambat dan ibu tidak memberikan ASI eksklusif kepada bayinya. Beberapa penelitian tentang pemberian ASI eksklusif dengan pertumbuhan bayi usia 0-6 bulan didapatkan bahwa bayi yang tergolong pertumbuhannya tidak normal paling banyak pada bayi yang tidak diberi kolostrum yakni 58,8\%, dan dari 122 bayi yang mendapatkan ASI eksklusif sebagian besar (95,10\%) memiliki berat badan normal dan sebagian kecil mengalami pertumbuhan berat badan lebih $(2,45 \%)$ dan pertumbuhan berat badan kurang yaitu sebesar $2,45 \%$. Dan yang tidak mendapatkan ASI eksklusif sebagian besar $(68,57 \%)$ mengalami berat badan yang kurang dan sebagian kecil (5,71\%) mengalami pertumbuhan berat badan yang normal, sedangkan yang mengalami berat badan sangat kurang yaitu sebanyak $28,12 \% .{ }^{15,16}$

Dampak kekurangan gizi terhadap tumbuh kembang anak telah cukup disadari oleh berbagai kalangan. Anak-anak yang kekurangan gizi akan mengalami gangguan pertumbuhan fisik, mental dan intelektual. Gangguan tersebut menyebabkan tingginya angka kematian dan kesakitan, serta berkurangnya daya tahan tubuh. Kekurangan gizi pada usia dini mempunyai dampak yang buruk pada masa dewasa dan dimanifestasikan dalam bentuk 19 fisik yang lebih kecil dengan produktivitas yang lebih rendah. ${ }^{17}$

\section{METODE}

Penelitian ini menggunakan desain potong lintang yang diselenggarakan di RSUP $M$ Djamil, beberapa puskesmas Kota Padang, dan Laboratorium Biomedik Fakultas Kedokteran Universitas Andalas. Subjek penelitian ini adalah ibu dan bayi yang melaksanakan ASI eksklusif, berumur 4-6 bulan, dan bersedia ikut dalam penelitian. Jumlah sampel minimal adalah 59 subjek dan diambil secara consecutive sampling. Subjek yang memenuhi kriteria dilakukan pemeriksaan berat badan bayi dan 
pemeriksaan IgA sekretori ASI.

Prosedur penelitian dilakukan dengan cara semua bayi yang memenuhi kriteria inklusi dan mengeluarkan kriteria eksklusi diambil sebagai sampel penelitian, kemudian dicatat data dasarnya. Dilakukan Pengukuran Berat Badan. Dilakukan pengumpulan ASI dengan cara: Payudara ibu dibersihkan kemudian dikeringkan, ASI diperas dan diambil sebanyak 5-10 cc, selanjutnya disimpan di dalam botol sampel yang steril dan ditranspor dengan cool box ke laboratorium. Tindakan ini dibantu oleh bidan atau perawat yang berkompeten. Dilakukan pemeriksaan kadar IgA sekretori dalam ASI dengan cara ELISA.

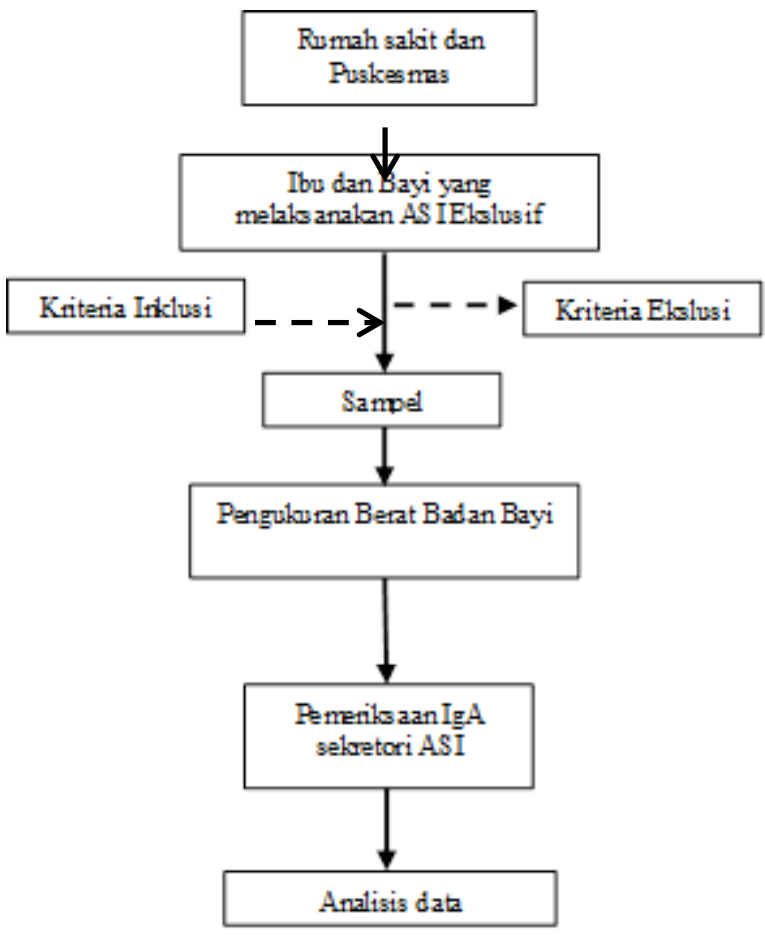

Alur Penelitian

Pemeriksaan ELISA dilakukan menambahkan $100 \mu \mathrm{L}$ reagen standar, atau sampel pada sumur reaksi. Sumur reaksi yang kosong diisi dengan pelarut sampel dan standar acuan. Lalu diinkubasi selama 90 menit pada suhu $37^{\circ} \mathrm{C}$. Buang pelarut, lalu tambahkan $100 \mu \mathrm{L}$ Biotinylated detection $A b$, dan inkubasi selama 1 jam pada suhu $37^{\circ} \mathrm{C}$. Lakukan aspirasi sumur reaksi dan cuci sebanyak tiga kali. Tambahkan larutan $100 \mu \mathrm{L}$ HRP conjugate pada setiap sumur reaksi, dan inkubasi selama 30 menit pada suhu $37^{\circ} \mathrm{C}$. Lakukan kembali aspirasi tiap sumur reaksi dan cuci sebanyak tiga kali. Tambahkan 90 L larutan substrat, dan inkubasi selama 15 menit pada suhu $37^{\circ} \mathrm{C}$. Tambahkan $50 \mu \mathrm{L}$ larutan stop, dan baca segera dengan menggunakan micro-plate reader pada $450 \mathrm{~nm}$ kemudian hitung hasil yang didapatkan.

Data yang diperoleh, dianalisis dengan mencari korelasi antara variabel menggunakan analisa statistik.

\section{HASIL DAN PEMBAHASAN}

Pada penelitian ini telah didapatkan 60 subjek yang memenuhi kriteria inklusi. Karakteristik subjek penelitian dapat dilihat dari tabel 1.1.

Tabel 1.1. Karakteristik Subjek

\begin{tabular}{cll}
\hline Karakteristik & $\begin{array}{l}\text { Jumlah } \\
(\mathrm{n}=60)\end{array}$ & $\begin{array}{l}\text { Persentase } \\
\%\end{array}$ \\
$\begin{array}{c}\text { Jenis Kelamin } \\
\text { Laki-Laki }\end{array}$ & 29 & 48,33 \\
Perempuan & 31 & 51,67 \\
Umur (bulan) & & \\
4 bulan & 33 & 55 \\
5 bulan & 20 & 33,3 \\
6 bulan & 7 & 11,6 \\
\hline
\end{tabular}

Subjek terbanyak adalah perempuan sebanyak $51,67 \%$ dan umur terbanyak adalah 4 bulan $55 \%$. Hasil pemeriksaan berat badan dan IgA sekretori pada subjek penelitian dapat dilihat pada tabel 1.2. 
Tabel 1.2. Hasil Pemeriksaan berat badan dan IgA sekretori

\begin{tabular}{llll}
\hline Parameter & Mean & SD & $\mathrm{p}$ \\
\hline $\begin{array}{l}\text { IgA sekretori } \\
\text { (ng/ml) }\end{array}$ & 17,305 & 3,14 & 0,908 \\
$\begin{array}{l}\text { Berat Badan } \\
\text { Bayi }(\mathrm{kg})\end{array}$ & 6,75 & 0,95 & \\
\hline
\end{tabular}

Kadar IgA sekretori rata-rata adalah 17,3 $\mathrm{ng} / \mathrm{ml} \mathrm{SD} \pm 3,14$, dan berat badan rata-rata adalah $6,75 \mathrm{~kg} \mathrm{SD} \pm 0,95$ Setelah dilakukan analisis statistik dengan menggunakan Analisis Bivariat Korelasi Pearson, didapatkan nilai p 0,908, dengan kesan hubungan tidak bermakna.

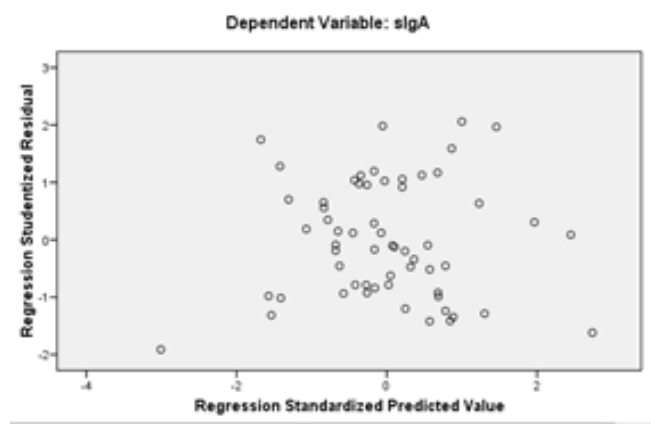

Gambar 1. Diagram Sebar

Telah dilakukan penelitian tentang hubungan kadar IgA sekretori dalam ASI dengan faktor pertumbuhan pada bayi yang mendapat ASI eksklusif. Pada penelitian ini jumlah sampel minimal adalah 54, tetapi untuk mencegah terjadinya drop out maka sampel ditambah $10 \%$ sehingga jumlah sampel menjadi 60 .

Jenis kelamin pada seluruh kasus hampir berimbang, namun didapatkan jenis kelamin perempuan lebih banyak daripada jenis kelamin laki-laki dengan usia rata-rata 4,5 bulan. Penelitian ini juga melihat gambaran berat badan, panjang badan, lingkar kepala, dan lingkar lengan atas yang kemudian dicari rata-rata, nilai maksimum dan nilai minimum untuk masing-masing faktor.
Pada penelitian ini didapatkan bahwa rata-rata berat badan anak-anak yang mendapat ASI eksklusif berada dalam rentang berat badan normal. Tidak ditemukan anak dengan berat badan di bawah normal. Hal ini sesuai dengan penelitian Suradi pada tahun 2011 bahwa anak yang mendapat ASI eksklusif akan mengalami percepatan pertumbuhan pada usia 4-6 bulan. Kadar slgA ASI dan berat badan bayi pada penelitian ini tidak didapatkan hubungan yang bermakna dikarenakan banyak faktor yang mempengaruhi berat badan bayi selama mendapatkan ASI eksklusif.

Pada penelitian ini didapatkan kadar ratarata IgA sekretori dalam ASI Ibu adalah $17,305 \mathrm{ng} / \mathrm{ml}$. Penelitian tentang profil imunoglobulin A dalam ASI pada ibu yang memiliki bayi cukup bulan dan kurang bulan, didapatkan hasil bahwa konsentrasi IgA menurun secara sejak minggu pertama menyusui. Konsentrasi IgA dalam ASI ibu dengan bayi prematur lebih tinggi dibanding ASI ibu dengan bayi cukup bulan, terutama pada awal-awal menyusui. Perbedaan konsentrasi IgA dalam ASI ibu dapat disebabkan oleh perbedaan usia gestasi ibu, perbedaan cara menyusui, atau perbedaan kondisi psikologis ibu atau aspek stres pada ibu. ${ }^{18}$ Kadar Ig A sekretori dalam ASI bervariasi cukup besar, pada beberapa penelitian disebutkan nilai rata-rata IgA sekretori pada kolostrum $2 \mathrm{~g} / \mathrm{dl}$, dan pada ASI matur berkisar 0,2-0,6 g/L, penurunan mulai terjadi sejak 4 hari menyusui. Menurut penelitian Henhart, kadar IgA sekretori pada ASI ibu yang tinggal di desa dengan status gizi lebih kurang rata-rata lebih tinggi dibanding dengan ibu yang 
tinggal di kota. Sedangkan kadar IgA sekretori cenderung tetap selama proses menyusui selam 18 bulan. Pada penelitian ini didapatkan hasil bahwa kadar IgA sekretori rata-rata dalam ASI pada ibu-ibu di Zairean lebih tinggi dari kelompok ibuibu di Eropa barat (Belgia). ${ }^{18,19}$

Sebuah penelitian telah dilakukan oleh Lawrence pada tahun 2007 tentang konsentrasi IgA sekretori dalam ASI selama tahun pertama menyusui pada 65 ibu menyusui di Gambia. ${ }^{4}$ Pada penelitian ini didapatkan hasil bahwa konsentrasi IgA median IgA dari seluruh sampel adalah $0,708 \mathrm{~g} / \mathrm{L}$, dengan rentang nilai dari 0,422-1,105 g/L. Tidak didapatkan perubahan yang bermakna terhadap nilai median kadar IgA sekretori pada seluruh populasi selama tahun pertama. Pada penelitian ini tidak didapatkan adanya hubungan antara jumlah ASI yang dihisap bayi dengan konsentrasi IgA dalam ASI. ${ }^{4}$ Selama musim panas nilai kadar IgA sekretori lebih tinggi dibanding musim dingin secara bermakna. ${ }^{20}$

ASI telah menunjukkan fungsinya untuk melindungi bayi dari berbagai jenis infeksi saluran cerna dan saluran nafas, terutama pada keadaan dimana higienis dan sanitasi jelek dan risiko infeksi tinggi. ${ }^{20}$ paritas yang rendah, usia ibu berhubungan dengan tingginya kadar IgA dalam ASI, tapi pada penelitian lain disebutkan kadar IgA lebih tinggi pada multipara. Terdapat hubungan yang bermakna antara kadar IgA sekretori dalam ASI pada payudara kiri dengan payudara kanan. ${ }^{20}$

Berdasarkan hasil uji statistik pada penelitian ini menunjukkan bahwa kadar
IgA sekretori pada ASI tidak berhubungan dengan berat badan pada bayi yang diberi ASI eksklusif dengan nilai $p>0,05$. Hal ini dapat terjadi karena pertumbuhan bayi dipengaruhi oleh banyak faktor, seperti faktor genetik dan faktor lingkungan biofisikopsikososial. ${ }^{21}$ Penelitian lainnya di Kota Padang mendapatkan hasil bahwa tidak terdapat hubungan antara pemberian ASI dengan tumbuh kembang bayi umur 6 bulan di Puskesmas Nanggalo Kota Padang. Hal tersebut menggambarkan bahwa ASI hanyalah salah satu faktor dari banyak faktor yang berpengaruh pada pertumbuhan dan perkembangan bayi. ${ }^{22}$

\section{KESIMPULAN}

Hasil dari Penelitian ini dapat disimpulkan bahwa tidak terdapat hubungan yang bermakna antara kadar IgA Sekretori pada ASI dengan berat badan bayi yang mendapat ASI Eksklusif. Petugas kesehatan hendaknya mempromosikan pemberian ASI eksklusif pada ibu hamil dan inisiasi menyusui dini (IMD) pada ibu melahirkan agar ibu termotivasi memberikan ASI eksklusif secara dini. Masyarakat hendaknya memberi dukungan untuk pemberian ASI eksklusif pada bayi sejak lahir sampai usia 6 bulan dengan cara memberi perhatian pada ibu menyusui agar ibu dapat memberikan ASI secara eksklusif kepada bayinya.

\section{UCAPAN TERIMA KASIH}

Penulis mengucapkan terima kasih kepada Fakultas Kedokteran Universitas Andalas atas penelitian yang dibiayai oleh dana 
DIPA PNBP Fakultas Kedokteran universitas Andalas, sesuai dengan Surat Perjanjian Pelaksanaan hibah Penelitian
Dosen Pemula sesuai dengan SK Dekan Nomor: 60/BBPT/PNP-FK-Unand-2016

\section{DAFTAR PUSTAKA}

1. National health and medical research council. Infant feeding guidelines. Canberra: National Health and Medical Research Council; December 2012.

2. Aldy OS, Lubis BM, Sianturi $P$, et al. Dampak proteksi air susu ibu terhadap infeksi. Sari Pediatri. 2009; 11(3):167-73.

3. American Academy of Pediatrics. Breastfeeding and the use of human milk. Pediatrics. 2012; 129:e827.

4. Lawrence RM, Pane CA. Human breast milk: current concepts of immunology and infectious diseases. Curr Probl Pediatr Adolesc Health Care. 2007; 37:7-36.

5. Matondang CS, Munasir Z, Sumadiono. Aspek imunologi air susu ibu. Dalam: Akib AAP, Munasir Z, Kurniati N, ed. Buku ajar alergi-imunologi anak. 2nd ed. Jakarta: Badan Penerbit IDAl; 2018. p189-203.

6. Queiroz VVO, Assis ANO, Junior HCR. Protective effect of human lactoferrin in the gastrointestinal tract. Rev Paul Pediatr. 2013; 31(1):90-5.

7. Mexitalia M. Air susu ibu dan menyusui. In: Damayanti RS, Lestari ED, Mexitalia M, Nasar SS, ed. Buku ajar nutrisi pediatrik dan penyakit metabolik. Jakarta: Badan Penerbit IDAl; 2011. p77-97.

8. Willer EM, Lima RL, Giugliano LG. In vitro adhesion and invasion inhibition of Shigella dysenteriae, Shigella flexneri and Shigella sonnei clinical strains by human milk proteins. BMC Microbiology. 2004; 4:18.

9. Sigit Sidi RS, Masoara S, Boedihardjo SD, Marnoto W. Manfaat Dan Keunggulan Asi. Jakarta: Perkumpulan Perinatologi Indonesia (PERINASIA); 2011.

10. Peakman M, Vergani D. Basic and clinical immunology. Second edition. London: Churcill Livingstone Elsevier; 2009. 36-44.

11. Abbas AK, Lichtman AH, Pillai S. Cellular and molecular immunology. Updated Edition. 6. International edition. Saunders Elsevier; 2010. 85-96.

12. Corthesy B. Roundtrip ticket for secretory IgA: role in mucosal homeostasis? The journal of immunology. 2007; 178:27-32.

13. Suradi R. Spesifitas Biologis Air Susu Ibu. Sari pediatri. 2001; 3:125-9.

14. Duijts L, Jaddoe VW, Hofman A, Moll HA. Prolonged and Exclusive Breastfeeding Reduces the Risk of Infectious Diseases in Infancy. Pediatrics. 2012; 129(3):e18-24.

15. Megawati RA, Notoatmojo H, Rohmani A. Hubungan Pola Pemberian ASI dan Karakteristik Ibu dengan Tumbuh Kembang Bayi 0-6 Bulan di Desa Bajomulyo, Juwana. Jurnal Kedokteran Muhammadiyah. 2012; 1(1):30-37.

16. Sucipto, Yenli SK. Hubungan Pemberian ASI dan Morbiditas dengan Pertumbuhan \& Perkembangan Bayi Usia 3 Bulan di Kecamatan Bandungan [Internet]. Semarang: Fakultas 
Kesehatan Masyarakat Universitas Diponegoro; 2012. [Disitasi 12 Mei 2016]. Diambil dari: eprints.undip.ac.id/38637/25-2-2013 diakses 12 Mei 2016)

17. Abdullah AZ. Surveilans Pertumbuhan Anak Melalui Pendekatan Learning Organization. Yogyakarta: Pustaka Timur; 2012.

18. Ballabio C, Bertinoi E, Cosciai A, Fabrisi E, Fuggetta D, Molfino S, et al. Immunoglobulin A profile in breast milk from mothers delivering full term adn preterm infants. J. Immunopathol. Pharmacol. 2007; 20:119-28.

19. Hennart PF, Brasseur DJ, Delogne-Desnoeck JB, Dramaix MM, Robyn CE. Lysozyme, lactoferrin, and secretory immunoglobulin A content in breast milk: influence of duration of lactation, nutrition status, prolactin status, and parity of mother. Am. J. Clin. Nutr. 1991; 53:32-39.

20. Weaver LT, Arthur HL, Bunn JEG, Thomas JE. Human milk IgA concentrations during the first year of lactation. Arch Dis Child. 1998; 78:235-9.

21. Soetjiningsih. Tumbuh Kembang Anak. Edisi 2. Jakarta: EGC; 2013.

22. Fitri DI, Chundrayetti E, Semiarty R. Hubungan Pemberian ASI Dengan Tumbuh kembang Bayi Umur 6 Bulan Di Puskesmas Nanggalo [Skripsi]. Padang: Universitas Andalas; 2012. 